
University of Edinburgh, School of Law

The Europeanisation of Citizenship in the Successor States of the Former Yugoslavia (CITSEE)

Citizenship and belonging in Serbia: in the crossfire of changing nationhood narratives Jelena Vasiljević

The Europeanisation of Citizenship in the Successor States of the Former Yugoslavia (CITSEE)

CITSEE Working Paper Series 2011/17

Edinburgh, Scotland, UK

ISSN 2046-4096 


\section{(C) 2011 Jelena Vasiljević}

This text may be downloaded only for personal research purposes.

Additional reproduction for other purposes, whether in hard copies or electronically, requires the consent of the authors.

Requests should be addressed to citsee@ed.ac.uk

The view expressed in this publication cannot in any circumstances be regarded as the official position of the European Union.

Published in the United Kingdom

The University of Edinburgh

School of Law

Old College, South Bridge

Edinburgh, EH8 2QL

Scotland, UK

www.law.ed.ac.uk/citsee/workingpapers

The Europeanisation of Citizenship in the Successor States of the Former Yugoslavia is funded by an Advanced Investigator Award for basic research made to Jo Shaw by the European Research Council and runs for five years from 1 April 2009 (ERC 230239)

For information about the Project please visit the project website at http://law.ed.ac.uk/citsee 


\title{
Citizenship and belonging in Serbia: in the crossfire of changing nationhood narratives
}

\author{
Jelena Vasiljević, University of Edinburgh ${ }^{1}$
}

\begin{abstract}
Drawing on the idea that politics of citizenship mirror specific ideas of nationhood, this paper aims to show how the changing citizenship regimes in Serbia translate the varying narratives and perceptions of nationhood into the realities of political community. The first part of the paper offers a short historical overview of the citizenship regimes practiced in Serbia, with an emphasis upon the socialist regime and the Milošević regime of the 1990s. Apart from providing necessary historical context, this section offers an insight into the important themes and topoi of Serbian nationhood narratives and their legal and political emanations. The second part deals with post-2000 Serbia and changes within the legal framing of citizenship status as well as the changes (or, in some respects, only partial changes) in the overall political climate. The third section of the paper shows how the current citizenship regime and dominant political narrative imagine Serbia's political community and accordingly manage groups and identities. Finally, the last segment of the paper briefly discusses the impact of Europeanisation taken both as a process of a political transformation and as a new emerging transformative discourse.
\end{abstract}

\section{Keywords:}

citizenship, Serbia, narratives, politics of belonging

\section{Introduction}

In 1992, when several of its former republics gained international recognition as independent states, the Socialist Federal Republic of Yugoslavia (SFRY) ceased to exist. Its breakup came on the wave of tectonic changes triggered at the end of "the short twentieth century" (Hobsbawm 1996). The collapse of the great ideological divide in the modern world was welcomed with high hopes of change; in Europe it gave the decisive push for accelerating the process of unification. But the crumbling of the Eastern Bloc and what was largely perceived as a triumphant turn towards the liberal democratic mode of governance turned out to pose far greater challenges for some countries than anticipated. In the case of the former Yugoslav states, democratisation came in the form of ethnocratisation, where long-awaited free elections brought basically ethno-national parties to power, even when hidden under "democratic" or different ideological names; the violent ethnic conflicts in which socialist Yugoslavia ended laid the foundations for the new states' (re)building processes and became inextricably intertwined with them.

\footnotetext{
Jelena Vasiljević, Research Fellow, CITSEE project. Email: j.vasiljevic@ed.ac.uk, jelena vasiljevic@yahoo.com.
} 
Each of the newly independent states ${ }^{2}$ faced the challenge to find legal and legitimising grounds on which to conceive its newly gained statehood: each was on its own search of ways to solidify territorial boundaries, to find unifying sociopolitical goals, to define its body of citizens; and each was confronted with internal discords and external pressures over these issues. The process of transformation of once internal Yugoslav republican boundaries into the external, international ones, and, moreover, the further attempts to equate republican-territorial units with nations ${ }^{3}$ was indeed challenging and almost unavoidably violent given "the difficulty (perhaps one should say in relation to the Balkans, the impossibility) of mapping nationality onto territory" (Allcock 1996: 66).

The issue of defining and managing citizenry proved to be of great importance and relevance for projecting the new polities' future trajectories. The questions of who can be a citizen, what the rules that define inclusion/exclusion are, what it means to exercise rights and duties in a given state, what the nature of the relationship between the state and its subjects is, are amongst the key matters determining the stability and nature of one polity and play a pivotal role in its initial stabilisation. In that respect, citizenship can indeed be seen as a tool of a modern (nation) state - suitable for helping to implement different national projects: from integration to ethnic engineering (Štiks 2010). For that reason looking at the newly installed citizenship laws and examining citizenship regimes that regulate both legal status and emotional attachments of citizens with their respective states can help to understand transformations that the former Yugoslav republics underwent. And these transformations were especially peculiar in the case of Serbia.

Dissolution of the SFRY left Serbia and Montenegro united in a rump Yugoslavia -

the Federal Republic of Yugoslavia (FRY), established in April 1992. In 2003 this was reconstituted as the State Union of Serbia and Montenegro; following the Montenegrin independence referendum, with 55.5 per cent of voters voting in favour of independence, Montenegro became an independent state in June 2006, leaving Serbia not much choice but to declare its own independence formally on 5 June of the same year. Therefore, Serbia's path to independence was carved through the process of other republics seceding from Yugoslavia and leaving the union with Serbia; establishing an independent Serbia was not part of the Yugoslav secession process,

\footnotetext{
2 Slovenia and Croatia were recognised as independent states by European Community member states on 15 January 1992 (although the Badinter Arbitration Commission ruled, on 11 January, that only Slovenia and Macedonia satisfied the criteria in the Guidelines on the Recognition of New States in Eastern Europe and the Soviet Union). Slovenia, Croatia and Bosnia and Herzegovina became members of the United Nations on 22 May 1992. The European Union did not recognise Macedonia until December 1993, due to Greece's objections to Macedonia's name and state insignia. For more on the politics and dynamics of international recognition of former Yugoslav republics see Trbovich 2008: 277-291.

${ }^{3}$ This equation was the expression of the process of increasing federalisation, which could be said to have started with the 1963 Constitution and decentralisation that "translated interethnic relations into interrepublican relations" (Ramet 1992: 54).
} 
but rather came as its final consequence. The absence of a pro-independence rhetoric in Serbia had much to do with Slobodan Milošević regime's legitimising strategies for staying in power in the 1990s: Milošević's ruling Socialist Party of Serbia (SPS) proclaimed legal and ideological continuity with socialist Yugoslavia. Such claims were used to justify and portray violent conflicts in Slovenia and in Croatia at the outset of the Yugoslav break-up, as the federal army interventions aimed at preserving the federal state's sovereignty. Their mobilising potential remained strong throughout the conflicts, and was often invoked to blur Serbia's own expansionist policies. But the rhetoric of the Yugoslav legacy was of even greater importance for internal use. Even though often portrayed as extremely nationalistic, and itself prioritised "national interests" in its agenda, the Milošević regime relied heavily on the rhetoric of continuity with socialism and the Yugoslav ideals of toleration and multiculturalism. This paradox created a maze of competing narratives amongst the Serbian public about national interests and the best ways of achieving them. It was also reflected in the everyday lives of Serbia's citizens. For instance, although officially and by declaration the state remained firmly secular (with Milošević's "socialists" in power), revitalisation of religion and religious manifestations testified to the growing power of the Serbian Orthodox Church and its links with nationalistic ideology. Even though the state officially insisted on preserving old institutions of social protection, poverty was becoming painfully visible and widespread. While officially recommending peaceful interethnic relations, the FRY regime instructed and supported policies that resulted in ethnic cleansing. While the insistence on Serb national interests was at the core of overall policies, the national sport teams still played under the insignia of Yugoslavia (Jansen 2005: 20-24). These paradoxes or parallel realities of confusing, often inconsistent ideologies and disturbing consequences present in everyday life mirrored the gap that Serbian regime of the 1990s created between its official rhetoric and practical politics. It was even present at the constitutional level: while other Yugoslav republics elevated their ethnonational policies to highest legal acts, through "constitutional nationalism" (Hayden 1992)4, Serbia adopted a civic constitution in 1990 with no traces of ethnic discrimination among its citizens and with no legal implications of any major intervention in its citizenry. However, at the same time, the Constitution abolished the autonomy of two Serbian provinces (Albanian-dominated Kosovo and to a high degree multiethnic Vojvodina), enabled the centralisation of power, and moreover - despite its "civicness" - left many individuals stripped of the civic and political rights attached to their status as citizens and, therefore, susceptible to various manipulations during the 1990s.

\footnotetext{
${ }^{4}$ Commenting on newly installed constitutional arrangements that favoured dominant ethnic groups, often by denaturalising large numbers of residents (belonging to minor ethnic groups), while at the same time adopting large numbers of non-residents (of "appropriate" ethnic origin), Hayden has nicely noted: "A better example of the power of the imagined community to destroy actually existing communities would be hard to find" (Hayden 1992: 666).
} 
After the democratic changes of 2000, Serbia entered the process of political and economic transition, which gave impetus to the formation of new narratives on ways to solidify the political and national communities. Abandoning the isolationist politics of the 1990s and setting Europeanisation as the goal of the highest priority shaped their framework. But an agreement on what would be the content was far from easy to achieve. Internal political destabilisation climaxed in 2003, with the assassination of Serbian Prime Minister Zoran Đinđić. In 2006, the state union with Montenegro fell apart. In the same year as it was left as an independent state, Serbia adopted a new Constitution, which now formally - but also at a symbolic level broke the ties with its socialist past and the "old state unions" by embracing the state insignia that evoked nineteenth century Serbian statehood. ${ }^{5}$ Symbolic attempts at projecting stability and Serbian statehood as a "long durée" fact were ruptured by territorial instability, its most effecting manifestation being the declaration of independence of Kosovo in February 2008. The state's politics towards Kosovo and its diplomatic efforts aimed at stopping its international recognition are often interpreted as being in conflict with the EU accession process. Moreover, it affects the citizenship status of many, not only of those residing in Kosovo, where Serbia maintains parallel institutions of government (especially in the northern parts of Kosovo), but also of many internally displaced persons (IDPs) whose residential and other rights are dependent upon the state's legal framing of secession of Kosovo.

These small sketches are given to illustrate the "problematic nexus between citizenship, nation-formation and state-building" in Serbia (Rava 2010). But given the ambiguity of the often differently interpreted notion of citizenship, I will now try to anchor in some of the theoretical dimensions which are relevant for the problems discussed in this paper. Firstly, it is worth noticing that renewed interest in the theorisation of citizenship, evident from the growing literature on the subject matter from the 1990s onwards, was partly triggered by the events like "the fragmentation of previously united multinational political communities such as Yugoslavia, the Soviet Union, Czechoslovakia..."; dissolution of certain types of polities for the purpose of creating new and different ones "raised anew deep questions about what binds citizens together into a shared political community" (Beiner 1995: 1,3). Citizenship, thus, primarily denotes formal state membership. But from it stems a more active dimension of citizenship: political rights and participation in political life which imbue the notion of citizenship with political power. Finally, citizens, in forming a political community and performing the rights that actively shape it, share a sense of communal belonging. Therefore, as Joppke suggests, it is useful to distinguish between citizenship as status, citizenship as rights and citizenship as identity (2007). The identity aspect of citizenship is especially theoretically challenging, but at the same time highly problematic to grasp and understand, because of its pretensions of universality (i.e. universal citizenship rights that stem

\footnotetext{
${ }^{5}$ On reasons and interpretations for evoking nineteenth century Serbia's state symbols see Malešević 2008.
} 
from citizenship status shared by all members of one state, as argued by T.H. Marshall) which are seen to be in collision with multiplicity of contested and differently represented identities that, in turn, challenge the equality implied by the universal citizenship status. ${ }^{6}$ Thus, the "identitarian struggles" and the politicised realm of groups' rights and groups' struggles for their legal recognition, which to a large extent mark the political condition of our time (sometimes portrayed as a trend of "global retraditionalization, see Milenković 2010: 127-148), are becoming intrinsic to any political project of (re)defining the body of citizens; status, rights and (politicised and many) identities are becoming increasingly harder to distinguish between, even for analytical purposes. This is especially true in the context of the post-Yugoslav countries where the issues of state consolidation are becoming dependent upon the efficient management of group identities (see Spaskovska 2010 and Sarajlić 2010). In this paper, I will put some emphasis on the institutional solutions (or, for that matter, the lack of them) for managing group identities and citizenry in today's Serbia.

Finally, when speaking about identity and citizenship, one usually has in mind the ethnic identity, especially in the context of the Balkans, where statehood, as in much of Central and Eastern Europe, has historically been understood as an ethno-territorial rather than a political project with nationhood frequently equated with ethnicity. However, it is important to distinguish between the often conflated notions of citizenship, ethnicity and nationality, having in mind that citizenship is primarily a state-related phenomenon (despite the proliferation of non-state related floating compounds like global, ecological, environmental, cultural etc. citizenship: see Oommen 1997: 223-229). On the other hand, the analysis in this paper will be mindful of Brubaker's argument that the politics of citizenship mirror specific ideas of nationhood (1998). I will show how the changing "citizenship regimes" (Shaw \& Štiks 2010) in Serbia - with an accent on the post-2000 developments - translate the varying narratives and perceptions of nationhood into the realities of political community. The research approach will rely on the model of questioning typical for the anthropology of policy which treats policy documents as cultural texts, as "...classificatory devices with various meanings, as narratives that serve to justify or condemn the present, or as rhetorical devices and discursive formations that function to empower some people and silence others"' (Shore \& Wright 1997: 15).

The first part of the paper will provide a short historical overview of the citizenship regimes practiced in Serbia, with an emphasis upon the socialist regime and the Milošević regime of the 1990s. Apart from providing the necessary historical context, this section will offer an insight into the important themes and topoi of Serbian nationhood narratives and its legal and political emanations. The second part will deal with post-2000 Serbia and changes within the legal framing of citizenship status as well as the changes (or, in some respects, only partial changes) in the overall

\footnotetext{
${ }^{6}$ For an overview of theories representing challenges that politics of identity pose to citizenship as universal political category, see Neš 2006: 177-187.
} 
political climate. The third section of the paper will show how the current citizenship regime and dominant political narrative imagine Serbia's political community and accordingly manage groups and identities. Finally, the last segment of the paper will briefly discuss the impact of Europeanisation taken both as a process of a political transformation and as a new emerging transformative discourse.

\section{Setting the grounding narratives: the development of Serbia's conceptions of nationhood and citizenship policies}

\subsection{From national awakening to Yugoslavia}

The modern nation-state building of Serbia began in the early nineteenth century with uprisings (in 1804 and 1815) in the central parts of today's Serbia against the Ottoman rule. These liberation movements belong within the historical framework of the nineteenth century national movements across Europe and were highly influenced by Herderian ideas of emancipating nations through common language and shared culture. However, due to the legacy of the Ottoman legal system of social differentiation between its subjects on the basis of religious identities (the millet system), the Serbian Orthodox church played a crucial role in defining the national identity of the Serb population. The intersection of these historical legacies and influences resulted in different visions of nationhood in the Balkans, from the idea that confessional boundaries should coincide with the political ones, to the emerging idea of linguistic nationhood. One of the most important manifestations of the latter was a significant historical event when writers from Serbia, Croatia and Slovenia gathered together and signed the so-called "Vienna literary agreement" (Bečki dogovor) in 1850, with an idea of bringing closer together and eventually uniting their respective languages and cultural heritage. Similarly, the idea of the territorial size of the polity in the making was a rather vague one, and was constructed on various sources of political imagination: from the idea of resurrecting the Serbian medieval kingdom and the Empire7- its "moderate" version being expressed in the idea of expanding Serbia's borders on the account of other Ottoman regions with large Orthodox Serb population - to embracing echoes of the Illyrian movement that was advocating a larger South Slav union. ${ }^{8}$ In addition, special

\footnotetext{
7 The Serbian medieval Kingdom developed through two centuries of its existence into the present days central Serbia, Macedonia, and Kosovo. The Empire (1331-1355) encompassed also the northern parts of modern Greece and Albania.

${ }^{8}$ The Illyrian movement was developed by the young intellectual elite in Croatia, then under the rule of the Austrian Empire, and it incorporated the ideas of the nineteenth century pan-Slavic movement. "Their aim was to regroup the Habsburg dominions into ethnic units, and they needed a broader base to extend Croatia's claim" (Pavlowitch 2003: 57). However, at that time, the emerging Serbian state felt little need for the Illyrian-Yugoslav vision and was reluctant to "give up a name upheld by Serbia's rising statehood" (Ibid). Instead, in its expansionist visions, it focused more on the idea of encompassing the Serb population "on the other side" of the rivers of Sava and Drina, i.e. on Austro-
} 
political ties bound the newborn Serbian principality with Montenegro, another emerging polity in the Balkans and area traditionally seen as the anchorage of the Serbian medieval legacy. ${ }^{9}$ The fight against Ottoman rule brought the Serbian principality into being and its state-like prerogatives: limited, but significant sovereignty, two dynasties - founded by the leaders of two uprisings, the first Constitution $^{10}$ and the civil code (in 1844) which regulated the citizenship in Serbia, and later in the Kingdom of Serbia. The Berlin Congress finally afforded Serbia (and Montenegro) international recognition and territorial enlargement in 1878. Serbia evolved into a kingdom in 1882, thus confirming its independent statehood.

The status of a sovereign state, together with further territorial expansion that came after the successes in the Balkan wars of 1912 and 1913, oriented Serbian expansionist policies towards other South Slavs and imbued it with Piedmont-like ideas and rhetoric. The political union of South Slavs was becoming more appealing as the plausible solution of gathering all Serbs into one state. The idea of Yugoslavism, carried and kept alive by large swathes of the South Slavic intellectual elite in the declining Austro-Hungarian Empire, gained even more convincing power at the outbreak of the First World War. Apart from engaging in it militarily, Serbia waged a diplomatic battle aimed at creating the new state that would emerge after the war. Three major negotiating parties were the Serbian government, the Yugoslav Committee (Habsburg South Slav political émigrés' body with its headquarters in London) and the National Council of Serbs, Croats and Slovenes (created by the South Slavic political parties of the Habsburg Monarchy's Austrian half in Ljubljana), representing the interests of South Slav people who were willing to unite in one state. The dominant position of Serbia was posited from the start with the acceptance that the ruling dynasty would be the Serbian Karađorđević royal family. But internal disputes over the institutional arrangements of the state became a disruptive factor from the outset of negotiations. Disagreements between the Serbian and Croatian representatives over the issue of whether the state should be set as a unitary or a federal composition emerged at the very beginning of the political life of new state. They erupted immediately after the state was born in December 1918, and took a dramatic turn during the talks that preceded the adoption of the new state's Constitution. According to the previous agreement, concluded before the war ended - the Corfu Declaration - the Constitution was to be adopted by a qualified majority. When the Serbian government realised that Croatian political parties were becoming

\footnotetext{
Hungarian territories inhabited by Serbs. These visions were expressed even in the policy documents of Serbian principality (Načertanije - the secret programme of exterior and national politics of Serbia, drafted by Ilija Garašanin, then Serbian Minister of the Interior, see Banac 1984: 82-84), and in its engagement in helping Serbs in Vojvodina who took part in the revolution of 1848.

${ }^{9}$ On the impact of the parallelism and connectedness of Serbian and Montenegrin ethnic and regional identities on the evolution of Montenegrin nationhood, see Džankić 2010.

${ }^{10}$ The Constitution known as the Sretenje Constitution was drafted in 1835, but was short lived since all the major powers influencing the polity in making (Austria, Russia, and the Ottoman Empire) found it to be too liberal. Their opinion coincided with that of the autocratic Serbian ruler Prince Miloš Obrenović who suspended it after only two weeks.
} 
increasingly in favour of the federalisation of the country, they imposed simple majority vote by which the Vidovdan Constitution was enacted in 1921. This was perceived by many as solidifying Serbian dominance in the largely centralised Kingdom of Serbs, Croats and Slovenes (Kraljevina Srba, Hrvata i Slovenaca). ${ }^{11}$ The struggles between the unitary and federal visions of the common state would mark the intense parliamentary life of the country, turning different visions of statehood into the major cause of political instability. The idea of politically reaffirming the existence of one organic Yugoslav nation, composed of "three ethnic tribes" was facing increasingly complex challenges.

The Citizenship Act of the new Kingdom was introduced only in 1928. The old legislature, as well as post-Second World War citizenship regulations (based on peace treaties with neighbouring countries), regulated the citizenship issues for ten years after the new Kingdom was born, which resulted in a fragmented citizenship regime. The new Citizenship Act referred to a single citizenship for the entire Kingdom, and thus testified about the attempts to create a cohesive legal framework and to solidify the national Yugoslav unity in order to oppose the growing ethnic strife in the country. Additional drastic measures were undertaken the next year, when an autocratic ruler, King Aleksandar Karađorđević, suspended the parliament, installed a royal dictatorship, and renamed the state the Kingdom of Yugoslavia. Another attempt to overcome the dramatically deepening fault line between the proponents of unitary and federal solutions was the partition of the state into regional districts (banovine) that ignored the ethnic divisions and stressed the geographic ones. Finally, the unitarist idea capitulated on the eve of the Second World War, when the Yugoslav government accepted Croatian demands to create a separate unit - the Banovina of Croatia, with its own ruler, ban, who would be responsible to the King and to the Sabor in Zagreb.

2.2 Serbia in resurrected Yugoslavia: from brotherhood and unity to the politicisation of grievances

The second Yugoslavia, born out of the ashes of the communist-led, solidary struggle against the occupier, brought the promise of resolving ethnic disputes through a new ideology of "brotherhood and unity" that would recognise its separate nations but insist on their political unity. But national and nationalistic politics were never entirely suppressed within socialist Yugoslavia, although its open expression became unacceptable within new ideological framework; rather, national liberation was elevated to a higher level through ideological battle against the occupiers, their war-time allies and the old royal system of governing. The new Yugoslavia was not so much a renewed project of creating Yugoslavs as it was a

\footnotetext{
11 The abbreviation for this in Serbo-Croatian was SHS, often interpreted, among the dissatisfied parties, as "Srbi Hoće Sve", meaning "the Serbs want it all" (Kazimirović 1995).
} 
project of creating new Yugoslav nations. Its specific governing frames introduced nations and nationalities as main constitutional categories (narodi $i$ narodnosti). Its internal arrangement through six republics and two provinces ${ }^{12}$ recognised the national emancipation of ethnies other than Serbian, Croatian and Slovene, notably Macedonian and Montenegrin. This was further confirmed through a specific twotier citizenship regime that set Yugoslavia apart from other multinational federal states of the communist block: the federal and republican citizenship existed simultaneously and, although the relation among them changed according to the constitutional changes in the state over the time, the hierarchy was never technically and legally clear. The evolution of constitutional changes (with federal and republican citizenship laws that changed accordingly) ${ }^{13}$ mirrored the evolution of politics of allocating republican sovereignty to their respective majority nations (with the exception of Bosnia and Herzegovina where no single group represented the majority historically). Over time this led to a system that, some believe, "could only be termed confederalism...or the domination of republics over the centre" (Bunce 1999: 111). With every new constitutional change the republics' competences grew. This led some scholars to believe that the purpose of the existence of the republican level citizenship was to confirm the quasi-sovereign status of the republics legally (Štiks 2010: 5-9). ${ }^{14}$ On the other hand, its practical implications were unclear to the citizens themselves, who often migrated and moved from one republic to another without changing their republican citizenship. That fact, coupled with the growing sovereign character of the republics - on which they would eventually claim their independence, at the dawn of the Yugoslav break-up - resulted in many persons becoming stateless and subject to various manipulations, when the new statebuilding and nation-building processes, involving profound redefinition of citizenship and citizenry of the new states, began in the early 1990s (Štiks: 2010: 9).

The growing power of the republican units, which developed into a political system based on "one republic one vote", with republican-like competences given even to the Serbian provinces of Vojvodina and Kosovo by the 1974 Constitution, laid

\footnotetext{
12 Immediately after the Democratic Federal Yugoslavia was established - then on 29 November 1945 renamed in Federal People's Republic of Yugoslavia - Vojvodina gained the status of an Autonomous Province, while Kosovo held the status of an Autonomous Region. In 1953, both were defined as districts and they became Autonomous Provinces in 1963.

${ }^{13}$ The changes in the federal citizenship laws followed constitutional changes - in 1945, 1963 and 1974. "While the 1946 law defined both citizenships as existing simultaneously, the 1964 law made republiclevel citizenship conditional upon federal citizenship. The 1976 law...decentralised competences for the implementation of citizenship regulation to the republics (e.g. registering citizens and issuing passports with their own codes)" (Rava 2010: 6.).

${ }^{14}$ The same process affected the status of two Serbia's Autonomous Provinces that after the last Yugoslav Constitution from 1974 basically acquired almost all competences of Yugoslav republics. One important exception was that they had never formally had their own citizenship, being legally attached to the citizenship regime of Serbia. However, their authorities received competences for issuing personal documents, so that passports of Vojvodina and Kosovo had their own codes ( $\mathrm{V}$ and KA; see Rava 2010; Krasniqi 2010).
} 
the foundations to narratives portraying Serbia's national interests as sidelined and suppressed. ${ }^{15}$ The trend of decentralising the country - confederalisation of Yugoslavia coupled with federalisation of Serbia - triggered the sentiment that Serbia has been increasingly underrepresented in Yugoslavia; that sentiment incorporated the elements from the old nationhood narratives, stressing the dominant role of Serbia in the South Slav union and its wartime efforts (in both World Wars) that proved decisive for the establishment of the state of Yugoslav nations in the first place; all of these narrative motives were interwoven into a presumption that Serbia had the "right to be the first among the equals" (Bunce, 1999: 116). Many of the growing national grievances found their expression in the notorious Memorandum, the draft document of the Serbian Academy of Sciences and Arts that was leaked to the press in $1986 .{ }^{16}$ General dissatisfaction was expressed through demands for the transformation of the country, where national grievances merged with the growing discontent over the socio-economic situation. A wave of riots and popular movements swept Serbia in the 1980s, reaching their highest intensity in Kosovo. A rising political star from the second half of the 1980s, the new leader of the League of Communists of Serbia, Slobodan Milošević, responded to popular movements in a populist way that differed in style from old party leaders' approach, and by engaging in the so-called "anti-bureaucratic" revolution against old cadres of the same party, won the hearts and minds of many. As Vladisavljević notes "the wave of popular politics served as the instrument which turned various socio-economic and political - nationalist and non-nationalist - struggles into nationalist conflicts... The critical actors that brought about the break-up of Yugoslavia were themselves transformed by the spread of nationalism..." (2010: 158).

\subsection{Ambiguous rhetoric: from preserving Yugoslavia to defending Serb interests}

After Milošević's Socialist Party of Serbia (founded as a merger of League of Communists of Serbia and the Socialist Alliance of the Working People of Serbia) took power, Serbia, together with Montenegro, became the exception among the former Yugoslav republics, in that it retained its "old-new" leadership after its first democratic elections. Milošević's distinctive combination of old party style ruling that co-opted and instrumentalised growing nationalistic sentiments paved the way

\footnotetext{
${ }^{15}$ The Serbs constituted the largest ethnic group in the SFRY (some 36 percent of the total population), but more than a third of them (in 1981, 3 million of the over 8.1 million in total) resided outside the Socialist Republic of Serbia.

${ }^{16}$ Although it became a common place in the scholarly analysis of Serbian nationalism to portray the Memorandum as a document envisioning Greater Serbia's plans and providing "ammunition for Milošević's nationalist campaign" (Lampe 1996: 6), much of these representations exaggerate the content of the text itself (but probably not the context of its production and its consequent instrumentalisation). See more in Dragović-Soso 2008: 18-20.
} 
for centralising all the power in Serbia; Serbia's Constitution of 1990 abolished the autonomy of the two Serbian provinces. ${ }^{17}$ However, as already mentioned, unlike other newly adopted constitutions of the former Yugoslav republics, the Serbian Constitution opted for a civic national determination. ${ }^{18}$ This was illustrative of the gap that characterised Milošević's rule between the legal and rhetorical frameworks of his power, on one hand, and ethno-national policies on the other. In other words, nationalistic fuel that kept him going was not the most visible marker of his rhetoric. One of the ways to understand the linkage between the centralisation of power and avoidance of nationalistic rhetoric is to look at it through prism of Gagnon's deconstruction of the idea that the wars in Yugoslavia were ethnic wars. He saw in Milošević's rule a continuation of practices previously employed by the conservative elite in the SFRY: whenever threatened with new political forces with potential to take over its own privileges, the elite would delegitimize them on the accounts of being nationalistic and secessionist (Gagnon 1995: 130-166). Thus nationalism and secession were conveniently used as a pretext for greater centralisation and preservation of power, and in Miloševićs Serbia even for military engagement. Higher ideological ends, seemingly above and beyond nationalistic aims would justify the concentration of all power. In the rhetoric of Serbian leadership and statecontrolled media nationalism became the feature of others/enemies ("separatist" Slovenians, "irredentist" Albanians, "fascist" Croats or "fundamentalist" Muslims) and openly endorsing its "qualities" on the domestic terrain, in circumstances created by Milošević's way of ruling, would have had delegitimising effects. However, the effects of Serbian ethno-politics were more than visible, not only during the wars in Croatia and Bosnia, but also in Serbia proper: most notably in Kosovo. The abolition of its status as an Autonomous Province was followed by the severe political and social discrimination of ethnic Albanians, who constituted vast majority in the region. Even though Kosovo Albanians formally had citizenship of the FRY and Serbia ${ }^{19}$ their rights were not secured - a situation which led to their self-exclusion and the establishment of parallel quasi-state institutions. (On elements of the Kosovo quasi-state and quasi-citizenship policies in the 1990s see Krasniqi 2010).

\footnotetext{
${ }^{17}$ Enacted in September 1990, one of its provisions related to the uncertainties of the development on the federal level: "If acts of the agencies of the Federation or acts of the agencies of another republic, in contravention of the rights and duties it has under the Constitution of the Socialist Federal Republic of Yugoslavia, violate the equality of the Republic of Serbia or in any other way threaten its interests, without providing for compensation, the republic agencies shall issue acts to protect the interests of the Republic of Serbia" (art. 135, Constitution of the Republic of Serbia, Official Gazette of Federal Republic of Yugoslavia 1/1990).

18 "The Republic of Serbia is a democratic state of all citizens living within it, founded upon the freedoms and rights of man and citizen, the rule of law, and social justice" (art.1).

${ }^{19}$ The law on Yugoslav citizenship in the new rump Yugoslavia re-established the two-tier citizenship, seemingly with the primacy of the federal citizenship over the republican. However, federal level organs had very little competences over the issues of status of citizens, which made citizenship policy of the 1990s highly problematic (Rava 2010: 8).
} 
The fact that there was a large group of citizens who formally enjoyed all rights, but were in fact politically and socially excluded illustrates the discrepancies between legal-political rhetoric and political reality. We could say that Kosovo Albanians were de facto excluded and that their exclusion had the form of the exclusion of "the other" within the framework of nationalistic politics. But there was also another sizable group of people that was left de jure excluded, even though it belonged to the same ethnic core into whose society its entry was denied. These were Serb refugees from Bosnia and Croatia, but this merits a brief note on the FRY's Law on Citizenship first.

The Law, enacted in $1996,{ }^{20}$ proclaimed the continuity with the citizenship of the SFRY, although many of its provisions did not support this claim, especially the conditions for obtaining the new citizenship. Those in possession of citizenship of the Republic of Serbia or of the Republic of Montenegro on 27 April 1992 (the day of the establishment of the FRY) became citizens of FRY ex lege (art. 46). Those with permanent residence on the territory of the two republics and who had citizenship of another republic of the former SFRY could register as citizens. However, they were required to make an application at the Federal Ministry of the Interior for an 'entry' into the register of citizens provided they did not have another citizenship (art. 47). The application had to be made within one year of the date when the law came into force. The main problem for that category of potential citizens - and most of them were Serb refugees that fled in great numbers (more than half a million people) from Bosnia and Croatia - was that many of them did not have permanent residence on the required date. The reasons for that were that many of them came to Serbia and Montenegro after that date, or they had difficulties in obtaining permanent residence in accordance with the laws at that time (Rava 2010: 9). Furthermore, the new citizenship law was only enacted in 1996 - four years after the state was established. One of the reasons for this delay could be, as is often argued, that the ruling elites were waiting to see the outcomes of the wars of Yugoslav succession. By imposing restrictions on the acquisition of FRY citizenship a manoeuvring space for politically manipulating the refugees was wide open. Firstly, the official vocabulary insisted on the term "expelled" (prognani) which was in line with the state's framing of the wars in neighbouring countries, in which it "officially never took part". Also, that expressed the expectation of the state that the "expelled" would return from where they were expelled and not settle permanently in the FRY. On the other hand, the state was trying to resettle some of them in areas where Serbs formed a minority, for the purpose of changing the demographic balance. There are indications that citizenship, in these cases, was directly used as a tool of ethnic engineering, via blackmail strategies: e.g. citizenship access would be granted if the family settled in Kosovo (Rava 2010: 10). However, a significant number of refugees remained

${ }^{20}$ Official Gazette of federal Republic of Yugoslavia, 33/1996. 
stateless for a long time. ${ }^{21}$ The reason for this could also lie in the uncertainties regarding their political loyalties. Even though they were Serbs who fled from ethnic conflicts, coming to Serbia with Milošević in power - portrayed as safeguard of Serb interests - the ruling party could not count with ultimate certainty on their votes (if granted citizenship). ${ }^{22}$ And that uncertainty, together with this short illustration of two different groups being de facto or de jure excluded on different grounds, concisely reveals the ambiguous nature of the official narrative (inclusive civil state, advocation of multinational Yugoslavia, protection of Serbs' interests) that, in turn, set the condition for the alternative (anti)nationalistic narrations to flourish, which targeted Milošević as the traitor of Serbian national interests, or as the one to be held most responsible for the wars and Serbia's isolation. That led to anti-Milošević narratives taking one of two forms: blaming him for causing the wars or blaming him for losing them.

\section{Serbia after 2000: grand narration restructuring or plus que ça change...}

\subsection{Changes in the legal framing of citizenship}

The fall of the Milošević regime in October 2000 signified for many the beginning of a democratic u-turn, the consolidation of democratic rule, the improvement of destroyed economy, the rebuilding of trustful dialogues with international political actors, and also, new directions in defining national interests, and even the redefinition of the national body itself. However, this path towards democracy would soon prove to be full of obstacles; the unanimous euphoria that seemed to be behind the opposition to Milošević would soon disintegrate into different, sometimes even mutually exclusive visions of post-Milošević Serbia. But, let me first start with the general outline of the changes that occurred within the legal framings of citizens' status within the new democratic settings.

Already in 2001, the federal parliament adopted changes to the existing law on citizenship, most notably a provision allowing dual citizenship, which, to a certain extent, made it easier for refugees to resolve their citizenship status. However, other issues, like the conflict between the federal and the republican laws on citizenship, as well as the question of citizenship of the Kosovo population, remained unaddressed (YUCOM 2001). The 1996 FRY citizenship act still applied, while on the republican level Serbia still depended upon the outdated law on citizenship enacted in 1979 (adopted to be in accordance with the 1974 SFRY Constitution)! The new reality in Kosovo, which was put in 1999 - following the NATO military intervention - under

\footnotetext{
${ }^{21}$ Some data indicate that only around third of applications for citizenship status was accepted (Rava 2010: 9).

${ }_{22}$ Since many refugees, especially those who fled from Croatia blamed the Belgrade regime for betraying them. For more on refugee electorate in Serbia see: Grujić 2006.
} 
the direct interim international administration of the United Nations, was not reflected in either of the laws.

Two years later, Serbia and Montenegro changed the framework of their common statehood. On February 2003, the FRY was transformed into the State Union of Serbia and Montenegro. Thus Yugoslavia finally vanished from the geo-political vocabulary and yet another state decomposition was on its way. The legal mechanisms that regulated the status and rights of citizens played their role. Starting from the end of the 1990s Montenegro began to implement politics that designated eloignment from Belgrade and Milošević's FRY. One of the moments that announced this political divorce was the enactment of Montenegrin law on citizenship of 1999. It read as if Montenegro were an independent state and reinforced the definition of Montenegrin citizenship as subsidiary to Yugoslav citizenship. According to that law, even a foreigner could theoretically have been able to obtain Montenegrin citizenship without necessarily becoming a Yugoslav citizen at the same time (YUCOM 2001). In addition to being in conflict with the Yugoslav citizenship act of 1996, it posited a rather restrictive citizenship regime (Džankić 2010: 10), thus preventing many from active participation in a polity that was on its way towards independence. The Constitutional Charter of the new state union between Serbia and Montenegro explicitly made republican citizenship superior to the one of the Union; the competence for the citizenship issues was fully devolved to the republican ministries of interior. Another important thing was that citizens of Serbia and of Montenegro, in this new transformed state, had equal rights and duties in the other state, except for the electoral rights. This proved to be of essential importance for the 2006 referendum on independence of Montenegro when the accordance of the voting arithmetic and laws granting the right to vote left more than 250,000 Montenegrins residing in Serbia out of the referendum process (whose positive outcome could have been otherwise put in question, with the total voting population in Montenegro of some 450,000 at the time, Džankić 2010: 11).

Setting the explicit primacy of the republican citizenship in the State Union meant that Serbia finally had to change its 1979 law on citizenship, which it did in December 2004..$^{23}$ The new Law on the citizenship of the Republic of Serbia tried to improve and harmonise the previous legal solutions with the international standards referring to acquisition and termination of the citizenship for the certain categories of people. It reflected visible efforts to incorporate the principles and norms of the European Convention on Nationality, even though Serbia had not ratified this (Miletić 2005: 41-44). The main goal of this law was to allow everyone who wished to obtain the Republic of Serbia's citizenship, and satisfied the elementary criteria, to do so more easily than before. It was initiated to leave out the previous conditions such as employment or other source of income, as well as condition of not being criminally prosecuted (see the report on Serbia in Imeri 2006: 267-285).

${ }^{23}$ Official Gazette of the Republic of Serbia, 135/2004. 
For certain special categories of persons, even the permanent residence on the territory of Serbia was no longer a requirement for entry into citizenship. Interesting too was the absence of any "ethno-cultural criteria" (e.g. the knowledge of Serbian language or the acceptance of Serbian culture), even though there were preferential conditions for admission into citizenship for persons belonging to Serb ethnicity. A very important feature of the actual law on citizenship is its toleration of dual and multiple citizenship which worked in direction of resolving the status of refugees: persons who on the date of enforcement of the law had citizenship of another former SFRY republic and who had permanent residence in Serbia for at least nine years, could become citizens under the sole condition of submitting a written statement that they accept Serbia as their state and without release from another citizenship (Art. $52)$.

The law also provided preferential treatment for several special categories of applicants. First, there was a possibility to acquire citizenship by a mere written statement and without release from another citizenship for those belonging to Serbian nation (understood in ethnic terms) and for those belonging to any other national or ethnic group from the territory of Serbia (art. 23). The same applied to emigrants from the territory of Serbia and their descendents (art. 18). Also, for all former citizens of Serbia who lost their citizenship, mainly due to former intolerance of dual citizenship, conditions to (re)obtain it are minimal (art. 34). ${ }^{24}$ And finally, a foreigner (and his or her wife or husband) could be granted citizenship, without meeting any conditions, if that was considered to be in the interest of the state (art. 19) (Rava 2010: 13).

Several important issues emerged from this legal re-conception of the body of citizens in a state that changed its political course (as well as its name and, after Montenegro's secession, sovereign status) and they will be approached, against the background of some other laws and the 2006 Constitution, in the following section. They include aspects of the ethnification of citizenship, together with legal treatment of minorities, political significance of dual citizenship, and (legal bypassing of) citizenship status of Kosovo residents. However, these changes and their implications can hardly be fully understood without an analysis of the post-2000 political climate in Serbia, with its clashing narratives of nationhood and statehood.

\subsection{Clashing political visions after Milošević}

Overthrowing Milošević's regime did not bring about an immediate break with its conceptual legacies. One of these "burdens" was the conception that has existed for a very long time: that Serbia is a nation rather than a state and that it does not exist beyond "Serbdom" (Dimitrijević 2009). The question of "national interests"

\footnotetext{
${ }^{24}$ This opportunity was mainly used by Jewish people who previously emigrated to Israel and by Bosniaks from Serbia's region of Sandžak who emigrated to Turkey.
} 
revolved around this idea and the legacy of imagining the nation in these terms proved to pose a major political as well as conceptual obstacle for the needed transformations. Becoming independent finally allowed Serbia to define its national interest in the sense of state interest only; it was the final, formal confirmation that "the national Piedmont" project was over. And, ironically, in the aftermath of Yugoslav secession process - when all the former republics finally became independent states - Serbia retained a truly multinational composition, with a sizeable population with non-Serb ethnic backgrounds.

Another "national project" became the basis for redefining the national interest: becoming a member state of EU. But, the general popular stance towards the process of EU integration is hard to assess. Public opinion polls show steadily increasing strong popular support for EU membership, but as some observers have noticed, this should be taken with some caution (Dimitrijević 2009). We should not underestimate the power of anti-Western sentiments that Milošević's propaganda nourished during the 1990s, and especially their aggravation during the NATO bombing in 1999. So it is not surprising to detect, alongside the support for becoming an EU member, a strong opposition to NATO membership. Strong emotional sentiments can easily disturb generally enthusiastic attitudes towards the EU, especially when the status of Kosovo enters the picture. Linking the two, in a manner of presenting the acceptance of Kosovo independence as a price to pay for European membership, potentially weakens the pro-European feelings in Serbia.

Another important element that should clearly designate the departure from the politics of the 1990s, and that many observers find noticeably missing (see Rakić Vodinelić 2009; Kuljić 2009) is taking a firm and unambiguous stance towards the crimes committed during the Milošević regime and, more generally, towards the role of the Serbian state in those crimes. And that stance should find its articulation both within the legal frameworks and general social awareness. However, steps towards a constructive dealing with the past are slow and widely contested among many political actors and citizens alike. Recent political events like the Declaration condemning the crimes committed in Srebrenica adopted in the Serbian Parliament, ${ }^{25}$ or President Tadić's visit to Vukovar and apologies for crimes committed in Croatia will hopefully indicate steps forward in much needed dealing with the past.

The democratic bloc that took power in 2000 was deeply divided over some crucial questions regarding the quality and speed of the reforms Serbia should undertake. The differences broke out immediately, with such intensity that led some observers to conclude that there were actually "two governments in power in the country" (Pešić 2009: 73). Although the comments depicting this division as rooted in a "two centuries old" political struggle between "liberals (modernists) oriented towards the West and conservative-nationalists (populists) ready to defend Serbian patriarchal society from Europe and 'Western depravity'" (Pešić 2009: 73) tend to

\footnotetext{
${ }^{25}$ The text of the Declaration can be downloaded from the official website of the National Assembly of the Republic of Serbia: http://www.parlament.gov.rs/content/eng/index.asp.
} 
oversimplify the clash, the division itself was severe and had real political consequences. It mainly revolved around uncertainties regarding the attitudes and political actions needed in relation to the legacy of the former regime. Due to disagreements within the ruling democratic bloc the political changes of 5 October 2000 were left incomplete. More importantly, there was no lustration and many of the key players from the old regime remained in power, instead of being prosecuted: at the insistence of the then President Koštunica's party, the head of the secret service stayed on for four more months after the changes and the head of the army for two more years. Some sources indicate that the secret service was, during this period, involved with destroying compromising documents (Bochsler 2010: 101). The crisis reached its peak with the assassination of Prime Minister Zoran Đinđić by the members of the special security units.

Disagreements about the sort and speed of reforms to be deployed, and attitudes towards the legacy of Milošević regime to be taken, influenced the formation of a very complex party politics structure in Serbia. The Democratic Opposition of Serbia, a coalition of numerous political parties that came to power in 2000, strongly advocated Serbian membership in the EU. The opposition or the 'antiEuropean bloc' consisted of previously ruling political parties, notably the SPS and the ultra-nationalist Serbian Radical Party. But soon after the changes the political parties' interrelations entered a phase of gradual transformation. The ruling bloc was severely threatened by the deepening fault line between Đinđić's Democratic Party (DS) and the Democratic Party of Serbia (DSS) led by Vojislav Koštunica. The DS favoured a radical break with the previous politics and rapid and overall changes in all the domains of the state apparatus. The DSS put preserving the legal order as its highest priority and insisted on the continuation of old structures of power and on slow pace of the reforms that would not jeopardise the existing legal system. Both parties expressed their strong pro-European inclinations, but the DSS resisted cooperation with the International Criminal Tribunal for the former Yugoslavia (ICTY), which was the main precondition for Serbia's EU integration. Gradually, the main opposition parties started taking different courses, most notably regarding the EU accession process; they softened their approach and moderated their rhetoric. In 2003, the Serbian Radical Party leader, Vojislav Šešelj, left the country to stand trial before the ICTY, leaving at the same time significant space for the leadership of that party to reposition its role in domestic political arena. In 2004, the SPS supported a minority government of the DS, thus indirectly returning to power and commencing its complete make-over that continues today. Currently, the SPS is part of a coalition government, while the leadership of the Radical Party has seceded and formed the Serbian Progressive Party. This is now the largest opposition party and it differs from the Radicals mostly in its acceptance of EU integration politics. Since Kosovo's declaration of independence, however, the DSS has become the loudest critic of integration politics finding them to be implemented at the cost of the indirect recognition of Kosovo secession. Crystallisation (or further complication?) of political attitudes concerning the future of Serbia's European perspectives and (non)related 
issue of Kosovo status came with the negotiations on the Stabilization and Association Agreement (SAA) with the EU, initialled in 2007. Since Kosovo declared independence in February 2008, the DSS strongly opposed the signing of SAA unless the EU recognises territorial sovereignty of Serbia. However, the Democratic Party and its coalition - which formed the government following the elections in May $2008^{26}$ - insisted on signing the Agreement, making the argument that Kosovo and EU are two different matters and that its politics relies on the imperative "both Europe and Kosovo".

In sum, we may conclude that general ideological principles (right/centre/left division) do not play crucial role in Serbian party politics; in addition to that, very often neither voters nor party members are familiar with ideology or party programmes (Lutovac 2007). Similarly, despite severe economic and transition problems, socio-economic dimension of party ideology plays an almost insignificant role in structuring the party system, in comparison to the identity politics dimension which completely dominates the sphere of political life. (Stojić 2010: 17-18). And it is precisely these politics of identity and belonging that find their way into the current constitutional and legal setting of Serbian citizenship regime.

\section{Managing and imagining the politics of belonging}

\subsection{The constitutional conundrum}

Much of the post-Yugoslav region is currently experiencing, to a certain extent, constitutional rearrangements that presuppose implementation of some aspects of multicultural politics - multiculturalism being understood mostly as securing different ethnic groups' rights. Many of the pressures leaning in that direction came also from external political actors, who in securing those rights saw the precondition for political stabilisation of the region. Direct outcomes of such policy making inclinations (or, rather, firm directives) came in documents like the Dayton Peace Accord or the Ohrid Agreement (or the Ahtisaari Plan, for that matter) that moulded the constitutional settings of Bosnia-Herzegovina and Macedonia. Even though their role in securing the functioning of political institutions in the immediate post-conflict context is beyond doubt, many have criticised their long term consequences as it is perceived that they inevitably ethnified all political issues. This was observed with regarding the situation in Bosnia-Herzegovina, where the link between the individual and the state is mediated through ethnicity, there has been "a significant trade-off between stability and human rights issues" (Sarajlić 2010: 20). In a more general discussion about this issue, there is a rising literature that points to the unfavourable consequences of claims of group differences and

\footnotetext{
26 The most recent elections of 2008 showed the strengthening of pro-European forces. The coalition that ran under the name For a European Serbia (Za Evropsku Srbiju) gained 38.75 per cent of the vote.
} 
discourses merging the rhetoric of rights and (ethnic) culture together. ${ }^{27}$ The debate itself surpasses the frame and purpose of this paper, but it should be noted that the "uneasiness" surrounding the concept of multiculturalism - is it a powerful tool for raising awareness of the cultural diversity or is it a fertile ground for "ethnoprofiteers"? (Milenković 2010: 75-93) - proves to be of some relevance in analysing contemporary institutional solutions aimed at the management of differences in Serbia.

In the same vein, the inconsistent and unclear deployment of main constitutional categories reveals much of the 'belonging conundrum'. For instance, the Preamble of the Constitution mentions 'the Serb people', 'all citizens and ethnic communities in Serbia' ${ }^{28}$ and part of its territory, Kosovo and Metohija. ${ }^{29}$ The way these different notions of belonging have been used in the same sentence, without clear explanation of their mutual relations - who is the bearer of the rights: members of the Serb people or citizens of Serbia? What is the difference? What is their relation to one part of the state mentioned in the same sentence of the Preamble? - suggest that Constitution did not really pay much attention to defining frameworks and settings for the management of now constitutionally recognised different belongings (Brković 2008). Brković further notices, in her analysis of the Constitution of Serbia, the failure to reconcile incorporated elements of multicultural polices with the liberal state legal framework: the Constitution guarantees the protection of individual human rights, and values personal liberties and freedoms highly, but at the same time the Constitution presupposes - by various usages of notions like identity, culture and tradition as ontological givens - the belonging of all individuals to (national) groups, cultures. Art. 64 illustrates the point that: 'Every child has a right...to maintain his or her identity'. Identity is clearly seen here as something that exists before the person is even born; it is implied that we acquire identity by the simple fact of being born in certain cultural surroundings. And what is even more worrying - and it is reflective of multicultural policies gaining more importance and political relevance in the Balkans - is that identity and culture are understood in the Constitution as ethnic identity and culture, as Brković's analysis shows (ibid). The Constitution takes into account the existence of different ethnic cultures in Serbia and even insists on ethno-cultural diversity and protection of ethnic minorities, but in a way that implies that Serbia is a community of (ethnic) communities. 'All citizens' from the Preamble seem to be completely absorbed by 'the Serb people' and 'ethnic communities in Serbia'. And not only that the civic element is somehow lost in these 'belonging arrangements', but the equality of all ethnic communities could be put in

\footnotetext{
${ }^{27}$ For example, Cowan, J.K. et al. (eds.) 2001.

${ }^{28}$ Again, in art.1: 'Serbia is a state of Serb people and all citizens living in Serbia', Official Gazette of the Republic of Serbia, 98/2006.

${ }^{29}$ It is mentioned three times in the Preamble: as having 'substantial autonomy within the sovereign state of Serbia' and 'from such status of the Province of Kosovo and Metohija follow constitutional obligations of all state bodies to uphold and protect the state interests of Serbia in Kosovo and Metohija in all internal and foreign political relations'.
} 
question as well. The initial differentiation between 'the Serb people' and other 'ethnic communities in Serbia' is replicated in many other legal settings as will be shown in the next segment on ethnification of Serbian citizenship. It is not just that the two 'categories' of citizens are often mentioned separately, it is the nature of state's relation towards the members of these categories that is potentially problematic. On one hand we have 'ethnic communities' that live in Serbia, with their members being citizens of Serbia. On the other, Serbia is defined as 'a state of Serb people', meaning not only of those Serb members living and residing in Serbia; in other words, not only of those who are actually citizens of Serbia. An illustration of that we can see in art. 13 of the Constitution, on 'protection of citizens and Serbs abroad' (my emphasis): 'The Republic of Serbia shall protect the rights and interests of its citizens in abroad. The Republic of Serbia shall develop and promote relations of Serbs living abroad with the kin state'. Quite clearly, the second sentence demonstrates the resolution of the Republic of Serbia to engage itself in promoting relations with those who ethnically - and not as citizens - 'own' it.

The 'ownership' of Serbia is also confirmed on a symbolic level. The adoption of the new Constitution had great symbolic importance, since it represented the first Constitution of an independent Serbia in more than a hundred years. It embraced the state symbols of nineteenth century statehood by adopting the royal coat of arms and the anthem that was in use until 1918. Obviously these resolutions testified to the attempts at creating a sense of continuation and rootedness in the old and thus allegedly stable traditions of statehood and nationhood. But, in fact, many other aspects related to the formulation and adoption of the Constitution revealed the ambiguities and contradictions of the 'old-new' state that was, in a way, in the process of its re-making: one of them clearly being the 'discrepancy between the featuring of clerical-monarchist icons - restored from the Kingdom of Serbia - on the one hand and the denomination of the modern Serbian state as a secular republic on the other' (Karamanić \& Šuber 2010: 16). The first article states that the country is founded on European values, the rule of law, human and minority rights, and principles of civic democracy. At the same time, Serbia is defined as a 'state of Serb people and all citizens living in it'. Serbia is defined as a nation state, with the Serbian language and the Cyrillic alphabet as the only national language. The final constitutional arrangements of a state that advocated political community with others (Milošević's rhetoric on preserving Yugoslavia and then insistence of Koštunica's government on the state union with Montenegro) eventually turned out to be those of an ethnic state (Malešević 2008).

\subsection{Ethnification of Serbian citizenship}

Upon the enactment of the Constitution and the break-up of the State Union in 2006, Serbian citizenship law was slightly amended in 2007, mainly to reflect these 
changes. ${ }^{30}$ For instance, although the same conditions still apply for members of Serb people and members of any other nationality or ethnicity from the territory of Serbia who wish to obtain citizenship, amended version distinguishes between ethnic Serbs who 'have the right to be admitted into citizenship' and persons of other ethnicities from Serbia 'who may be admitted into citizenship' (art. 23, my emphasis). This differentiation was probably introduced to harmonise the law with the Constitution that defines Serbia as a state 'of Serb people and all citizens who live in Serbia'. This has, however, raised some questions about the 'ethnification' of citizenship, a question that obviously cannot be assessed with a sole focus on the law on citizenship.

Since the only criterion is ethnic belonging, that raises questions about how to validate claims of belonging to 'Serb people' in general and to any other ethnicity from the territory of Serbia. The usual procedure of validation involves proving a family relationship with a resident of Serbia who claimed belonging in past census records or who is affiliated with certain diaspora organisations abroad. This brings us to a need to consider the Law on Diaspora and Serbs in the Region, enacted in 2009. ${ }^{31}$ Mostly, it envisages the opportunities for cultural and economic cooperation, but the very need to initiate a special law on diaspora (and even the Ministry of Diaspora) and the new formulation of 'the Serbs in the region' could be taken as indicative of new politics of post-territorial 'reassembling' of the nation, understood primarily as the ethnic nation. Even though the Ministry of Diaspora tends to promote a more inclusive notion of diaspora, art. 2 of the Law clearly distinguishes between two categories of that notion: citizens of the Republic of Serbia who live abroad, on the one hand, and members of Serb people, both from the republic of Serbia and from the region, who emigrated, as well as their descendents, on the other. 'Serbs from the region' encompasses ethnic Serbs who live in the republics of Slovenia, Croatia, Bosnia-Herzegovina, Montenegro, Romania, Albania, and Hungary. Apart from protecting the rights and interests of members of the diaspora and Serbs from the region, the Law states as its goals the 'protection and fostering of the Serbian language and the Cyrillic alphabet, as well as Serbian cultural, ethnic, linguistic and religious identity' (art. 4). It could be argued that such policies are in line with the new forms of ethnic nationalism, characteristic of the 'post-territorial citizenship' taking place in many post-Yugoslav states - 'where the presence on the territory is not anymore a relevant criterion of belonging to the community' (Ragazzi \& Balalovska 2010).

Another move towards 'de-territorialised' citizenship is the toleration of dual citizenship which entered into Serbian law in 2001.32 Although it is becoming increasingly accepted that dual citizenship should be protected as a human right (Spiro 2010), in the post-Yugoslav space it raises some concerns. Its introduction was

\footnotetext{
30 Official Gazette of the Republic of Serbia, 90/2007.

31 Official Gazette of the Republic of Serbia, 88/2009.

32 Official Gazette of the FRY, 9/2001.
} 
intended to facilitate the status of refugees as well as the return of the diaspora whose expert help was expected in conducting political and economic reforms. Therefore, it signified first steps towards liberalisation of the citizenship regime, but at the same time it proved to have a problematic impact on the politics in the region. One example is the unsettled issue of double citizenship between Serbia and Montenegro. After Montenegro declared independence, a significant number of persons found themselves in unfavorable position: Montenegrins who were citizens or residents of Serbia and Serbs who were citizens or residents of Montenegro. The Serbian Law provided preferential conditions for Montenegrins and dual citizenship, while Montenegrin Law on citizenship - due to specific voting arithmetic, internal political struggles between pro-Serb parties and the advocates of Montenegrin independence - prohibited dual citizenship (for more see Džankić 2010: 20-22). The situation is even more complicated due to strong social and familial connections between the citizens of the two countries and an agreement on the incompatibility between the two laws has not yet been reached.

Secondly, the question of dual citizenship per se raises the issue of state allegiance and state affiliation and its consequences bear specific importance for politically unstable states of the region. This is especially true with regard to consociational arrangements in Bosnia-Herzegovina, whose neighbours are 'national homelands' for a great number of Bosnian citizens. Although, Serbia has not been providing Serbian citizenship en masse to Bosnian Serbs, as was the case with Croatia and Bosnian Croats (Sarajlić 2010: 12), the politics of the 'Serbs from the region' might be expected to encourage further steps in that direction. However, it remains indicative that the Prime Minister of Republic of Srpska, Milorad Dodik, was admitted to the citizenship of Serbia in 2007.

\subsection{Serbia's minorities}

The total population of Serbia without Kosovo, according to the 2002 census, is $7,498,001$. Minorities account for 14.38 per cent of the population. The largest minority is Hungarian, the only one at more than 3 per cent of the entire population, followed by Bosniacs, Roma, Croats, Albanians, Romanians, and others (Lošonc 2009).

Serbia's ethnic diversity has often been seen in contrast with its weak institutional capacities to regulate such pluralism. Special conditions are needed to maintain cultural diversity and some observers find them to be missing in Serbia, starting from a conceptual level: instead of redefining the nation as a complex political community, the new 2006 Constitution is 'imbued with elements that perceive the state as a means of "national self-realization", conserving national minorities within a similar "instrumental" context' (Lošonc 2009: 93). And institutional solutions suffer from Serbia being a 'permanently unfinished state, with [a] still weak institutional matrix' (Lošonc 2009: 93). Minority institutions do exist, 
their number is even growing, but their abilities to enhance the political representation of minorities are questionable. After October 2000, Serbia made several important steps aimed at ameliorating its minority policies. For instance, in 2001, Serbia signed the Framework Convention for the Protection of National Minorities, and in 2005, the State Union ratified the European Charter for Regional or Minority Languages. In 2002, the Law on the Protection of the Rights and Freedoms of National Minorities was enacted as well. ${ }^{33}$ It entitled minorities to a bundle of rights: the right to preserve their language, culture and national identity, to receive education in their mother tongue until high school, to use their national symbols, and to be appropriately represented in the public sector. ${ }^{34}$ Seemingly the most important decision envisaged by the law was the creation of national minority councils. They are envisaged as legal entities with fifteen to 35 members, depending on the total number of members of a minority in question. However, even though the Law on Minorities prescribed representation in the form of national councils, it remained ambiguous about their functions and left open questions over their legal status (Lošonc 2009: 99). According to the law, national councils were supposed to regulate issues important to cultural identities of minorities: language and alphabet, education, communication, and culture. In reality, due to insufficient financial resources, their role had no significant effect on the status and quality of life of minority communities. In addition, many observers have noted that the method of electing the members of minority councils hardly helps representing heterogeneous interests of minority communities. Instead, they help the preservation of the existing minority elites (Lošonc 2009: 97). ${ }^{35}$

Thus, two conclusions can be made on the minority policies situation in Serbia. First, even though legal protection for minorities is secured, the same cannot

\footnotetext{
${ }^{33}$ Official Gazette of the Republic of Serbia, 11/2002.

${ }^{34}$ In addition, in 2007 some measures were introduced to facilitate the access of national minorities to parliament; a major change in the electoral law abolished the necessary requirement of passing a 5 per cent threshold for minorities' parties and lowered the number of signatures needed for submitting an electoral list from 10,000 to 3,000.

${ }^{35}$ However, in August 2009, the Serbian Parliament passed a new Law on National Minority Councils, which clarified some of the NMCs' competences, while also implementing a more transparent, more democratic system of direct elections to select NMC members. Under the previous system, NMC members were selected through a process of indirect elections, in which a college of electors from each national minority voted candidates onto the Council. However, under the new system, NMC members are directly elected - but only if a certain, high percentage of the members of that national minority register in a special list to vote in the elections. If not, the old system continues to apply. One particular area of change in the new National Minority Council Law could have a major impact namely, new competences given to the NMCs in the field of public information, or the distribution of news via print or broadcast media. In the interest of preserving the constitutionally guaranteed right of national minorities to be informed about the news in their own language, the 2009 law gives National Minority Councils the power to unilaterally take over the ownership rights of municipally owned, minority-language television or radio stations, and then fund (using state money) and control programming and editorial policy at these stations (for more see the OSCE web page: http://www.osce.org/serbia/69574).
} 
be said about an effective means for their political representation. And secondly, we can observe a trend of incorporating minority elites into the framework of majority elites, which only creates an illusion that minorities take part in the political system and that they are adequately represented in the political life.

\subsection{The Kosovo dilemma}

On 10 June 1999 Kosovo was put under direct international administration in accordance with UN Resolution 1244. The administration and the legislative and executive power were placed in the hands of the United Nations Interim Administration Mission in Kosovo (UNMIK). Legally, Kosovo residents remained Yugoslav citizens, but UNMIK created a separate Central Civil Register of Kosovo which regulated residency status and issued travel documents to Kosovo residents. This was needed because many Kosovo residents were left without any identification papers after the NATO bombing. Kosovo Albanian officials stated that the civil registries were purposefully destroyed, while Serbian authorities claimed that all the registries were transferred to different Serbian municipalities. However, the situation regarding the regulation of citizenship status of Kosovars, after the implementation of the 1244 Resolution, was such that Serbia continued to regard all Kosovars as its own citizens, although some possessed only the UNMIK documents, whereas some were still in possession of the FRY or Serbian documents, especially passports.

The status process negotiations began in October 2005. Since no compromise was reached after two years and fifteen rounds of negotiations, Martti Ahtisaari, in the role of the Special Envoy of the Secretary-General of the United Nations for the future status of Kosovo presented in March 2007 the so-called Ahtisaari Plan Proposal for the Kosovo status Settlement - to the Security Council. Due to Russia's objections, the negotiations continued, without any result which led to Kosovo's political representatives unilaterally declaring independence on 17 February 2008. Adoption of the Constitution and the law on Kosovo citizenship followed soon after (see Krasniqi 2010).

Serbian citizenship policies towards Kosovo reflected all the complexity of the situation which had been developing since NATO's intervention. In its highest legal act as well as in its Law on citizenship, the state of Serbia does not reflect the factual changes that have occurred nor the fact that it has no effective control over the citizenship issues in Kosovo, since the presence of Serbian Ministry of Interior on the territory of Kosovo is constrained by the 1244 Resolution. One of the effects of that situation was non-inclusion of Kosovo residents in the Schengen visa liberalisation regime applied to Serbia in December 2009. According to the EU, since it could not exercise control over the territory, Serbian Ministry of Interior was not in a position to issue biometric passports to Kosovo residents, required for the visa-free travel into the Schengen space. This has created a situation where the whole population of Kosovo is affected by discriminatory citizenship practices such as exclusion of people 
(or, at least, tacit complicity in the EU imposed exclusion) from one region from the benefits enjoyed by all other citizens. In addition, the very same region is regarded as the integral part of Serbia's territory - which is mentioned even in the Constitution's Preamble. Kosovo's authorities meanwhile issue their own documents and passports which Serbia does not recognise. These issues, together with the presence and activism of Serbian state in the northern parts of Kosovo, where the majority of the Serb population lives, work in direction of creating competing citizenship regimes in Kosovo.

\section{Conclusion: Europeanisation in the matrix of existing narratives}

The political relationship between Serbia and the EU is rather complex given the contradictory and often problematic relations that Serbia has had with the EU Member States over the past two decades. The uniqueness of this relationship is manifested in the substantially different views the two sides have on the basic issues - such as, for instance, where the boundaries of Serbia are and what is Serbia's population. The Serbian Constitution defines Kosovo as part of its territory, and thus deems all political actions that would claim the opposite as unconstitutional. On the other hand, the majority of EU countries, although not all, have recognised Kosovo's independence, ${ }^{36}$ and that lack of unanimity within the EU, whose law and order mission in Kosovo (EULEX) took over the UNMIK, makes things even more complicated.

In January 2011, the European Parliament ratified the Stabilization and Association Agreement (SAA) with Serbia after a long and difficult process. Serbia's recent past and its involvement in wars in Croatia and Bosnia, and even more so, its ambiguous and undetermined political stances adopted after the democratic change in 2000, stood in way on its European path. The ratification of the SAA was put on stand-by for quite some time due to an estimated lack of political will of the state establishment to cooperate fully with the ICTY. After finally arresting and handing Radovan Karadžić over to the ICTY in the summer of 2008, very little progress has been made in locating other fugitives convicted of war crimes, most notably Ratko Mladić and Goran Hadžić, who are believed to have been enjoying active support from some parts of the Serbian state apparatus.

There is a general consensus that the process towards joining the EU is slow and full of obstacles. Although strict conditionality, from the part of EU, has been criticised as an insufficiently productive approach, scholars and analysts mostly emphasise 'domestic' factors related to the deceleration of the process. Causes of insufficiently effective process of EU integration are predominantly to be found in the lack of consensus, among the leading democratic pro-European parties and, some argue, in underdeveloped political culture in Serbia (Vujadinović 2009: 131). As

\footnotetext{
${ }^{36}$ Romania, Slovakia, Cyprus, Spain, and Greece have not recognised Kosovo.
} 
discussed earlier in this paper, the democratic coalition that overthrew Milošević could not establish an agreement on the path of the democratic changes to be taken and on the policy of discontinuity from the previous regime. Liberal nationalists, led by then President of Serbia Vojislav Koštunica and his Democratic Party of Serbia prevented the politics of decisive legal, institutional and general discontinuity from the previous regime. The assassination of Prime Minister Zoran Đinđić seriously endangered transformation process further, and the ensuing parliamentary elections, in December 2003, showed a growing support for the anti-systemic parties (Vujadinović 2009: 127). The lack of cohesive elements in political attitudes toward EU integration was mirrored in general public opinion. The problematic aspects of generally positive, but substantially incoherent public opinions on the EU, mentioned earlier, were also registered in many surveys. What they usually discover is a discrepancy between cognitive support (rational insight into the need for EU integration) and emotional distance, provoked by negative experiences of UN sanctions and NATO bombing. They also show that European integration is valued highly, as an ultimate goal, but the instrumental means deployed in achieving this goal provoke criticism and sceptical attitudes (Baćević 2001).

Europeanisation understood in a narrow sense as meeting the membership criteria of the EU does not exhaust all the implications of the term for the process of social and political transformation that Serbia has undergone under its rhetorical power. Within the context of member states, Europeanisation means 'the emergence in the EU of distinctive structures of governance'. However, for non-member states such as Serbia, 'what matters is not how the European institutions evolve, but the efforts of such institutions to promote EU's values and institutional models in nonmember countries' (Baracani \& Di Quirico 2005: 11, 12). We have seen how the rhetoric of Europeanisation and differences in perception of the kinds of political actions that should stem from it, have shaped the party political structure in the country. It was introduced within the frame of general transition as a powerful narrative that gives certain value to every major political or social act. Thus many recent events that have occupied media space in Serbia - cooperation with ICTY, organisation of Gay Pride, outbursts of hooligan violence on the streets, president Tadićs visit to Vukovar - have been assessed from the stand-point of this crucial question: how far have we gone in the process of Europeanisation and what are the obstacles that need to be overcome? Or, in alternative narratives, where is the limit of its seemingly endless conditionality and what will its impact on Serbian nationhood be?

We have seen how the various narratives of statehood and nationhood run parallel to political changes, at times reinforcing them, at times creating obstacles for their implementation, but nevertheless providing the keys in which they are to be interpreted. The legislature reflects this interplay, as a way of codifying and 
legitimising political directions taken by a polity at one time. Citizenship regimes are important manifestations of these directions since their codification sends messages about polity's boundaries, internal arrangements and management of constitutive citizens. Through the last one hundred and fifty years conceptions of Serbian nationhood developed and were filtered by different ideas about community in which it should express itself. Expansionist policies, nurtured by Piedmont-like ideas and a national remembrance of the 'medieval glory' that emerged in the nineteenth century soon had to be compromised with more realistic and politically 'up-to-date' ideas of South Slavic unification. The unitary Yugoslav citizenship project failed, only to be resurrected in another unifying project, with new powerful overarching ideology, where, for the first time, did not only South Slav people get to live in one state, but also received their state prerogatives and developed their ideas about respective republican citizenships. Some aspects of it proved to be fatal as wars on Yugoslav succession, and employment of restrictive citizenship regimes and politics used in them, have shown us. Political and military involvement of Serbia in these wars with 'ethnic semi-democratic' regime of Slobodan Milošević (Bieber 2005) created very complex and problematic maze of nationhood narratives with competing ideas about the 'Serbian interest' and visions of Serbian polity. They reflected the overall political and social chaos in which all Serbian citizens lived through the 1990s. Democratic changes brought the promise and hope of resolving these issues, but many of the legacies - as we now discover - are hard to dismantle and it proves to be difficult to create a sound and uncompromised ground for a 'fresh start' for the newly independent Serbian state and its citizenry. Many of the old narratives are still present, but they will inevitably change, form different patterns of interaction with each other, and finally be forced to leave space for the new 'European' one to find its own place within this matrix of narratives.

It is clear that Europeanisation, as a transformative power, does not only work on the institutional level. Its efficiency equally depends on rhetorical framings and interplay with other existing (and politically supported and reinforced) trans/formative narratives. It will be interesting to see the further developments and the political effects on the Serbian citizenship regime of their intertwined structure as Serbia progresses on its path to EU integration. 


\section{Bibliography}

Allcock, J. B. (1996), 'Borders, states, citizenship: unscrambling Yugoslavia' in F. W. Carter \& H. T. Norris, The changing shape of the Balkans. Boulder, CO: Westview Press.

Baćević, Lj. (2001), Serbs and Europe. Belgrade: The Centre for Anti-War Action. Banac, I. (1984), The national question in Yugoslavia. Ithaca/London: Cornell University Press.

Baracani, E. \& R. Di Quirico (2005), 'Introduction', in R. Di Quirico (ed.), Europeanisation and democratisation. Florence: European Press Academic Publishing.

Beiner, R. (ed.) (1995), Theorizing citizenship. Albany: State University of New York Press.

Bieber, F. (2005), 'Serbia in the 1990s: the case of an ethnic semi-democracy', in S. Smooha \& J. Priit (eds.), The fate of ethnic democracy in post-communist Europe. Budapest: Open Society Institute.

Bochsler, D. (2010), 'The party system of Serbia', in V. Stojarova \& P. Emerson (eds.), Party politics in the Western Balkans. London/New York: Routledge.

Brković, Č. (2008), 'Upravljanje osećanjima pripadanja: Antropološka analiza "kulture" i “identiteta" u Ustavu Republike Srbije', Etnoantropološki problemi, 3(2): 5976.

Brubaker, R. (1998), 'Immigration, citizenship and the nation-state in France and Germany', in G. Shafir (ed.), The citizenship debates. Minneapolis: University of Minnesota Press.

Bunce, V. (1999), Subversive institutions. Cambridge: Cambridge University Press. Constitution of the Republic of Serbia. Official Gazette of Federal Republic of Yugoslavia, $1 / 1990$.

Constitution of the Republic of Serbia. Official Gazette of the Republic of Serbia, 98/2006.

Cowan, J. K., M-B. Dembour \& R. A. Wilson (eds.) (2001), Culture and rights: anthropological perspectives. Cambridge: Cambridge University Press.

Declaration of the National Assembly of the Republic of Serbia condemning the crime in Srebrenica. http://www.parlament.gov.rs/content/eng/index.asp. 
Dimitrijević, V. (2009), 'The concept of national interest and the international position of Serbia', in D. Vujadinović \& V. Goati (eds.), Serbia at the political crossroads. Belgrade: CEDET and Friedrich Ebert Stiftung.

Dragović-Soso, J. (2008), 'Why did Yugoslavia disintegrate? An overview of contending explanations', in L. J. Cohen \& J. Dragović-Soso (eds.), State collapse in South-Eastern Europe. West Lafayette, IN: Purdue University Press.

Džankić, J. (2010), 'Lineages of citizenship in Montenegro', CITSEE Working Paper, School of Law, University of Edinburgh.

Gagnon, V. P. (1995), 'Ethnic nationalism and international conflict: the case of Serbia', International Security, 19(3): 130-166.

Grujić, J. (2006), 'The refugee electorate: past, present and future'. Migrationonline.cz, http://www.migrationonline.cz/e-library/?x=1963588.

Hayden, R. M. (1992), 'Constitutional nationalism in the Formerly Yugoslav Republics', Slavic Review, 51(4): 654-673.

Hobsbawm, E. (1996), The age of extremes. New York: Vintage.

Imeri, S. (2006), Rule of law in the countries of the Former SFR Yugoslavia and Albaniabetween theory and praxis. Gostivar: Association for Democratic Initiatives.

Jansen, S. (2005), Antinacionalizam. Beograd: XX vek.

Joppke, C. (2007), 'Transformation of citizenship: status, rights, identity', Citizenship Studies, 11(1): 37-48.

Karamanić, S. \& D. Šuber (2010), 'The visual between norm and excess', paper presented at the conference 'Audiovisual media and identity in Southeastern Europe', Wittenberg.

Kazimirović, V. (1995), Srbija i Jugoslavija, 1914-1945. Kragujevac: Prizma.

Krasniqi, G. (2010), 'Citizenship as a tool of state-building in Kosovo: status, rights, and identity in the new state', CITSEE Working Paper, School of Law, University of Edinburgh.

Kuljić, T. (2009), 'Remembering crimes - proposal and reactions', in D. Vujadinović \& V. Goati (eds.), Serbia at the political crossroads. Belgrade: CEDET and Friedrich Ebert Stiftung. 
Lampe, J. R. (1996), Yugoslavia as history: twice there was a country. Cambridge/New York: Cambridge University Press.

Law on Diaspora and Serbs in the Region. Official Gazette of the Republic of Serbia, $88 / 2009$.

Law on the amendments and additions to the Law on Yugoslav Citizenship. Official Gazette of Federal Republic of Yugoslavia, 9/2001.

Law on the amendments and additions to the Law on Citizenship of the Republic of Serbia. Official Gazette of the Republic of Serbia, 90/2007.

Law on Citizenship of the Republic of Serbia. Official Gazette of the Republic of Serbia, $135 / 2004$.

Law on the Protection of the Rights and Freedoms of National Minorities. Official Gazette of the Republic of Serbia, 11/2002.

Law on Yugoslav Citizenship. Official Gazette of Federal Republic of Yugoslavia, 33/1996.

Lošonc, A. (2009), 'Political representation as an expression of the relationship between majority and minority', in D. Vujadinović \& V. Goati (eds.), Serbia at the political crossroads. Belgrade: CEDET and Friedrich Ebert Stiftung.

Lutovac, Z. (2007), Ideologija i Političke Stranke u Srbiji. Belgrade: Friedrich Ebert Stiftung.

Malešević, M. (2008), 'Nasilje identiteta', in Kulturne paralele: svakodnevna kultura u postsocijalističkom periodu. Beograd: Etnografski Institut SANU.

Milenković, M. (2010), Ka politici srpske antropologije u 21. veku. Beograd: Odeljenje za etnologiju i antropologiju Filozofskog fakulteta u Beogradu i Srpski genealoški centar.

Miletić, S. (2005), Zakon o državljanstvu Republike Srbije sa komentarom i prilozima. Beograd: Službeni list Srbije i Crne Gore.

Neš, K. (2006), Savemena politička sociologija. Beograd: Službeni glasnik.

Oommen, T. K. (1997), Citizenship, nationality and ethnicity. Cambridge: Polity Press.

Pavlowitch, S. K. (2003), 'Serbia, Montenegro and Yugoslavia', in D. Djokić, Yugoslavism: histories of a failed idea 1918-1992. London: Hurst \& Company. 
Pešić, V. (2009), 'Nationalism of an impossible state: a framework for understanding the unsuccessful transition to legitimacy in Serbia', in D. Vujadinović \& V. Goati (eds.), Serbia at the political crossroads. Belgrade: CEDET and Friedrich Ebert Stiftung.

Ragazzi, F. \& K. Balalovska (forthcoming), 'Diaspora politics and post-territorial citizenship in Croatia, Serbia and Macedonia', CITSEE Working Paper, School of Law, University of Edinburgh.

'Raising awareness of the National Minority Council elections in Serbia', OSCE Mission to Serbia. http://www.osce.org/serbia/69574.

Rakić Vodinelić, V. (2009), 'Should war crimes denial be incriminated in Serbia?', in D. Vujadinović \& V. Goati (eds.), Serbia at the political crossroads. Belgrade: CEDET and Friedrich Ebert Stiftung.

Ramet, S. (1992), Nationalism and federalism in Yugoslavia, 1962-1991.

Bloomington/Indianapolis: Indiana University Press.

Rava, N. (2010), 'Serbia: elusive citizenship in an elusive nation-state', CITSEE Working Paper, School of Law, University of Edinburgh.

Sarajlić, E. (2010), 'A citizenship beyond the nation-state: dilemmas of the 'Europeanisation' of Bosnia and Herzegovina', CITSEE Working Paper, School of Law, University of Edinburgh.

Shaw, J. \& I. Štiks (2010), 'The Europeanisation of citizenship in Former Yugoslavia: An introduction', CITSEE Working Paper, School of Law, University of Edinburgh. Shore, C. \& S. Wright (eds.) (1997), Anthropology of policy. London/New York: Routledge.

Spaskovska, L. (2010), 'In search of a demos: transformations of citizenship and belonging in the Republic of Macedonia', CITSEE Working Paper, School of Law, University of Edinburgh.

Spiro, P. J. (2010), 'Dual citizenship as human right', International Journal of Constitutional Law, 8(1): 111-130.

Stojić, M. (2010), 'Between post Yugoslav legacy and European opportunities - The changing nature of Serbian political parties' attitudes towards the EU', Paper presented at the 40th UACES Annual Conference, Bruges. 
Štiks, I. (2010), 'A laboratory of citizenship: shifting conceptions of citizenship in Yugoslavia and its successor states', CITSEE Working Paper, School of Law, University of Edinburgh.

Trbovich, A. S. (2008), A legal geography of Yugoslavia's disintegration. Oxford: Oxford University Press.

Vladisavljević, N. ( 2010), 'The break-up of Yugoslavia: the role of popular politics' in, D. Djokić \& J. Ker-Lindsay (eds.), New perspectives on Yugoslavia. London: Routledge.

Vujadinović, D. (2009), Serbia in the maelstrom of political changes. Belgrade: Faculty of Law of the University of Belgrade.

YUCOM (2001), Serbian-Montenegrin relations and the question of citizenship of FRY citizens, Executive summary. 

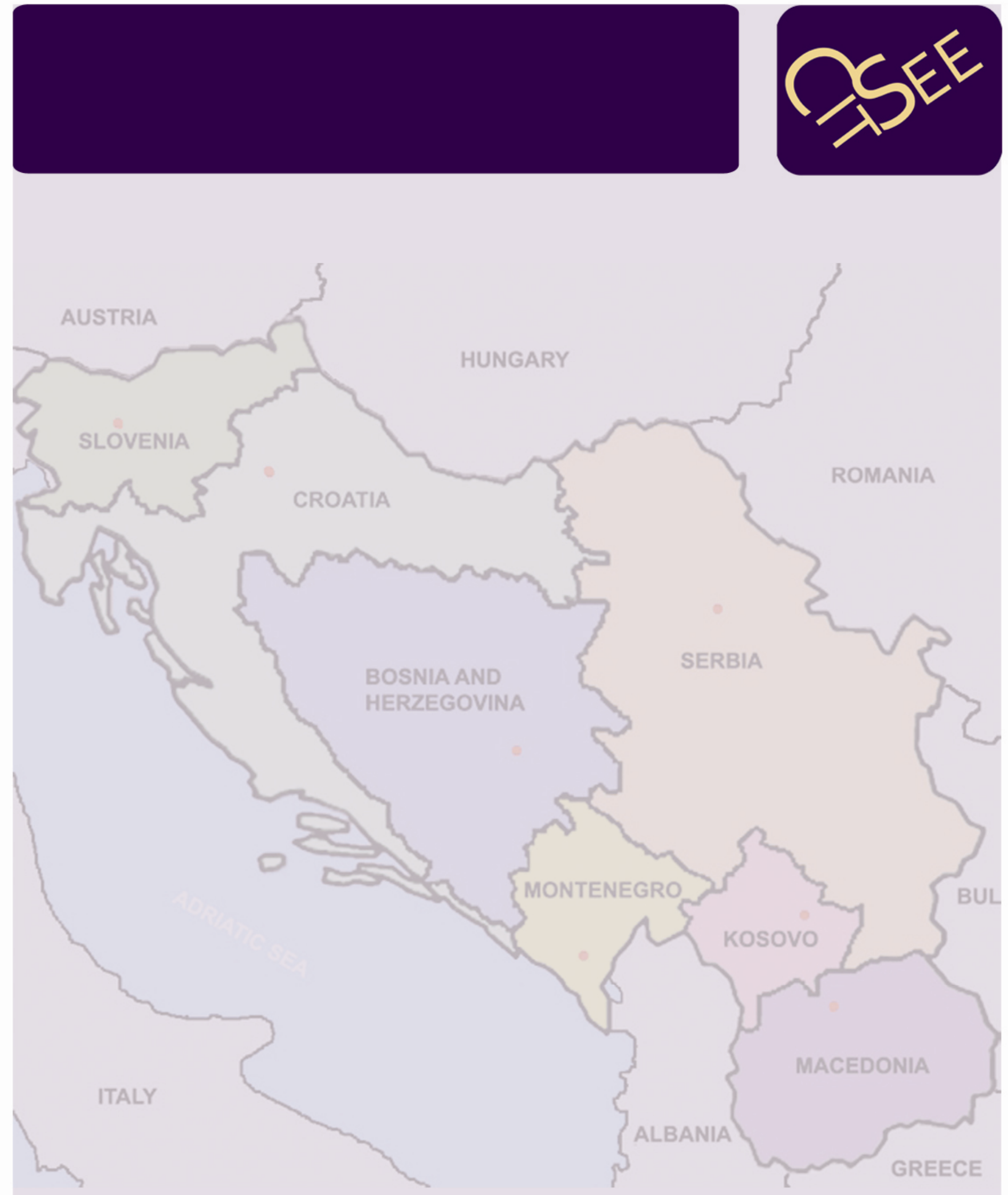

I S N 2046-4096

The EUROPEANisation OF Citizenship in the SUCCESSOR States of the FORMER YugosLavia (CITSEE) SCHOOL OF LAW, THE UNIVERSITY OF EDINBURGH,

OLD COLLEGE, SOUTH BRIDGE

EDINBURGH, EH 8 gYL, SCOTLAND, UK

WWW. LAW, ED, AC, UK/CITSEE 